\title{
TEMPORARY SERIES OF HEAT SOURCES IN MESOREGIONS OF PARAÍBA, BRAZIL
}

\author{
Danilo Brito Novais ${ }^{1}$, Patrícia Carneiro Souto², Jacob Silva Souto², José Augusto da Silva Santana ${ }^{3}$
}

\begin{abstract}
${ }^{1 *}$ State University of the Southwest of Bahia, Graduate Program in Agronomy, Vitória da Conquista, Bahia, Brazil - *danilobn@ gmail.com ${ }^{2}$ Federal University of Campina Grande, Department of Forest Engineering, Patos, Paraíba, Brazil - pcarneirosouto@ yahoo.com.br, jacob_souto@yahoo.com.br

${ }^{3}$ Federal University of Rio Grande do Norte, Natal, Rio Grande do Norte, Brazil - gutossantana@ gmail.com
\end{abstract}

Recebido para publicação: 06/09/2017 - Aceito para publicação: 08/11/2018

\begin{abstract}
The management of fire is a set of decisions directed to practices of prevention, verification and control of this agent that can modify the landscape. Remote sensing helps in understanding the phenomena that occur on the earth's surface. This work had the objective of analyzing the occurrences of heat sources recorded by satellites in the State of Paraíba (2000 - 2015). The occurrences of heat sources were selected by months of the year making it possible to visualize the frequency of heat sources in different locations. It is observable that the years with the highest number of heat sources in Paraíba were 2003, 2004 and 2009. In the six municipalities studied, 3.712 heat sources were recorded, with Cajazeiras municipality having the highest number of records (2.253 occurrences). It is concluded that the highest occurrence of heat sources inthe studied regions runs from September to December, where the Sertão Paraibano mesoregion was the one with the highest incidence of heat sources, being the most affected by fire. It is recommended, thus, the implementation of awareness programs that inform the citizens of rural and urban areas about the importance of adequate fire management in order to reduce heat sources in the region.

Keywords: Forest fire; precipitation rainfall; semi-arid paraibano.
\end{abstract}

\section{Resumo}

Série temporal de focos de calor em mesorregiões da Paraíba. O manejo do fogo é um conjunto de decisões direcionadas a práticas de prevenção, constatação e controle desse agente modificador da paisagem. O sensoriamento remoto auxilia no entendimento dos fenômenos que ocorrem na superfície da terra. Este trabalho teve como objetivo analisar as ocorrências dos focos de calor registrados por satélites no Estado da Paraíba (2000 - 2015). Foram selecionados seis municípios que estão distribuídos nas quatro mesorregiões do estado. Os dados analisados foram obtidos de uma série temporal de 15 anos (2000 a 2015). As ocorrências dos focos de calor foram selecionadas por meses do ano, possibilitando visualizar a frequência dos focos de calor em distintas localidades. Pode-se observar que os anos com maior número de focos de calor na Paraíba foram 2003, 2004 e 2009. Nos seis municípios estudados foram registrados 3.712 focos de calor, sendo o município de Cajazeiras o que obteve o maior número de registros (2.253 ocorrências). Conclui-se que, a maior ocorrência de focos de calor, para as regiões de estudo, vai de setembro a dezembro, onde, a mesorregião Sertão Paraibano foi a de maior incidência dos focos de calor, sendo a mais atingida pelo fogo. Recomenda-se, então, a implantação de programas de conscientização que informem o cidadão das zonas rural e urbana sobre a importância do adequado manejo do fogo, de modo a reduzir os focos de calor na região.

Palavras-chave: Incêndio florestal; precipitação pluviométrica; semiárido paraibano.

\section{INTRODUCTION}

Fire management is described by Ramos et al. (2016) as a series of decisions aiming practices of prevention, verification and control and, through it, manipulation of landscapes according to the defined objective. For this reason, fire is an important agent that modifies the landscape, often necessary in ecological processes, but in most cases, it gets out of control and promotes immeasurable damages to terrestrial ecosystems.

Every year, fires extinguish forests all over the world. The propagation of these fires is related to climatic conditions, with a direct effect on their speed and intensity of propagation. Relative humidity, wind speed and temperature are the main factors in relation to burning (SORIANO et al. 2015), as well as the lack of rainfall, and the quantity and quality of combustible material and relief.

In Brazil, according to data provided by the National Institute for Space Research (INPE, 2017), in the period from 2005 to 2016, 4.31 million hotspots were recorded. These hotspots may be due to urban or forest fires, burnings and any other surface that emits heat at a temperature perceivable to the sensors of thermal satellites. Regarding the areas affected by forest fires in Brazil, 5.58 million $\mathrm{km}^{2}$ were burned during this period, in which Cerrado, Amazon and Caatinga biomes represent $91.2 \%$.

FLORESTA, Curitiba, PR, v. 49, n. 2, p. 181-188, abr/jun 2019.

Novaes. D. B. et.al.

ISSN eletrônico 1982-4688

DOI: $10.5380 /$ rf.v49 i 2.55112 
In addition to the lack of knowledge about Caatinga, which is already devastated by agricultural advance and extraction of firewood for energy, forest fires are becoming more intense every year, causing irreversible damages (SANTANA; SOUTO, 2006; SANTANA et al., 2011). In this way, the establishment of fire monitoring, control and prevention strategies are extremely important. For this, forest fire statistics are a fundamental tool (PEREIRA et al., 2014), since it helps to define the main sites and times of occurrence and causative agents (TORRES et al., 2016). However, one limiting factor to these statistics is often the lack of information and standardization of data on forest fires, being hotspots an alternative to help decision making.

In this way, the remote sensing shows itself as a valuable tool in obtaining these data, once it allows interpretations of the phenomena that occur on Earth's surface through the spectrum of each target by detecting and locating hotspots in real time. This is possible because of investments in technology in Brazil, which facilitate the monitoring of hotspots in record time, help very much in the fight against forest fires (GRANEMANN; CARNEIRO, 2009; PEREIRA et al., 2014).

Since 1980, INPE has been improving the detection of fires by means of sensors installed in satellites, capturing hotspots that are detected on Earth's surface, which emit temperatures above $47^{\circ} \mathrm{C}$ in an area of at least $900 \mathrm{~m}^{2}$ (RODRIGUES et al., 2014). Currently, INPE uses several satellites that have optical sensors, generating hourly images, which are processed to detect hotspots, however, to compose a database and form a time series that allows the comparison of incidences over the years, reference satellites are utilized, including NOAA-12 (June 1998 to July 2002) and, since then, the AQUA_M-T.

As hotspots do not occur homogeneously, in addition to identifying them, it is also necessary to know the periods in which they occur most, considering the characteristics of each region, months of the year and periods with climatic changes, such as El Niño, which causes greater periods of drought and, consequently, the appearance of more intense fires in the North and Northeast of Brazil (PEREIRA, SILVA, 2016).

Therefore, the aim of this study is to analyze the occurrences of hotspots recorded by satellites in the state of Paraíba, Brazil (2000 - 2015), in order to provide information that will assist in the prevention and combat of forest fires, since the emergence of these fires varies according to the region of incidence and particular conditions of each period.

\section{MATERIAL AND METHODS}

\section{Areas of study}

The state of Paraíba lies within the Caatinga biome between coordinates $6^{\circ} 02^{\prime} 12^{\prime \prime} / 8^{\circ} 19^{\prime} 18^{\prime \prime} \mathrm{S}$ and $34^{\circ} 45^{\prime} 45^{\prime \prime O}$ and covers an area of 56,47,000 km² (Brazilian Institute of Geography and Statistics - IBGE, 2018), being one of the smallest states in Brazil, but with a great diversity of landscapes and mesoregions, divided, according to the Superintendency of Environmental Management (SUDEMA, 2004), in Paraiba Forest, Agreste, Borborema, and Sertão.

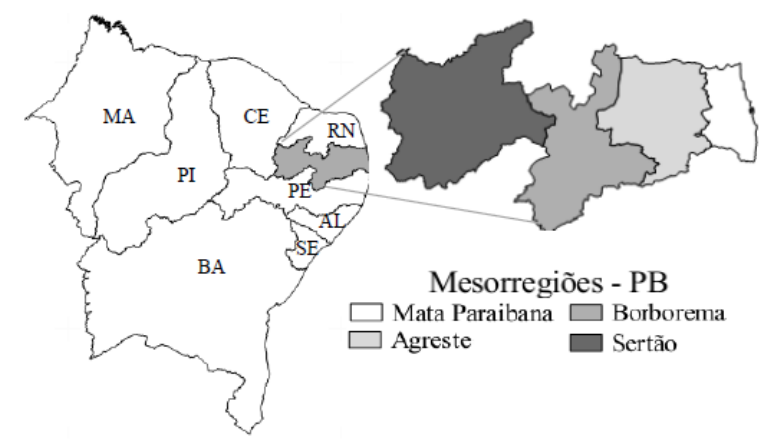

Source: Soares et al. (2016)

Figura 1. Localização do estado da Paraíba com delimitação das mesorregiões e municípios onde foi realizado o estudo.

Figure 1. Location of the state of Paraíba with delimitation of the mesoregions and municipalities where the study was carried out.

The climate in the state is characterized by high average temperatures ( 22 to $30^{\circ} \mathrm{C}$ ), with a small annual thermal amplitude, the months with lower temperatures go from June to August and the hottest months between October and December, being those months with lower rates of rainfall precipitation (VAREJÃO-SILVA et 
al.,1984; FRANCISCO et al., 2015). Rainfall ranges from 400 to $800 \mathrm{~mm}$ annually in the semiarid regions and in the coast, which is more humid, being possible to exceed 1,600mm (VAREJÃO-SILVA et al., 1984).

\section{Obtaining and analyzing data}

In order to carry out the present study, data were obtained on hotspots occurred in the state of Paraíba, Brazil, in a time series of 15 years (2000 to 2015), being recorded by reference satellites of INPE. Six municipalities were selected, in which the hotspots were quantified through all the satellites that feed the INPE database, distributed in all mesoregions and that have meteorological stations of the National Institute of Meteorology (INMET), which accompanies, stores and makes available rainfall data on a daily basis.

Based on the obtained survey, it was possible to separate the occurrence of hotspots in months of the year, which allowed to visualize the frequency in different localities. The survey data was evaluated using the Excel spreadsheet editor. Then, the annual averages were calculated and the graphs of hotspots in the mesoregions were elaborated.

\section{RESULTS}

The data obtained from the satellite database provided by INPE enabled us to verify that, in 15 years, there were 11,307 heat sources in the state of Paraíba, where there were years with a greater number of hotspots, specifically in 2003, 2004 and 2009 (Figure 2). These variations may be related to rainfall and annual temperatures, once drier, hotter years favor the emergence of hotspots due to the ease of fire propagation, as rainier years allow a greater accumulation of biomass, which is a fundamental element as for as combustible for flames becoming, then, a component of the fire triangle, in addition to rural practices.

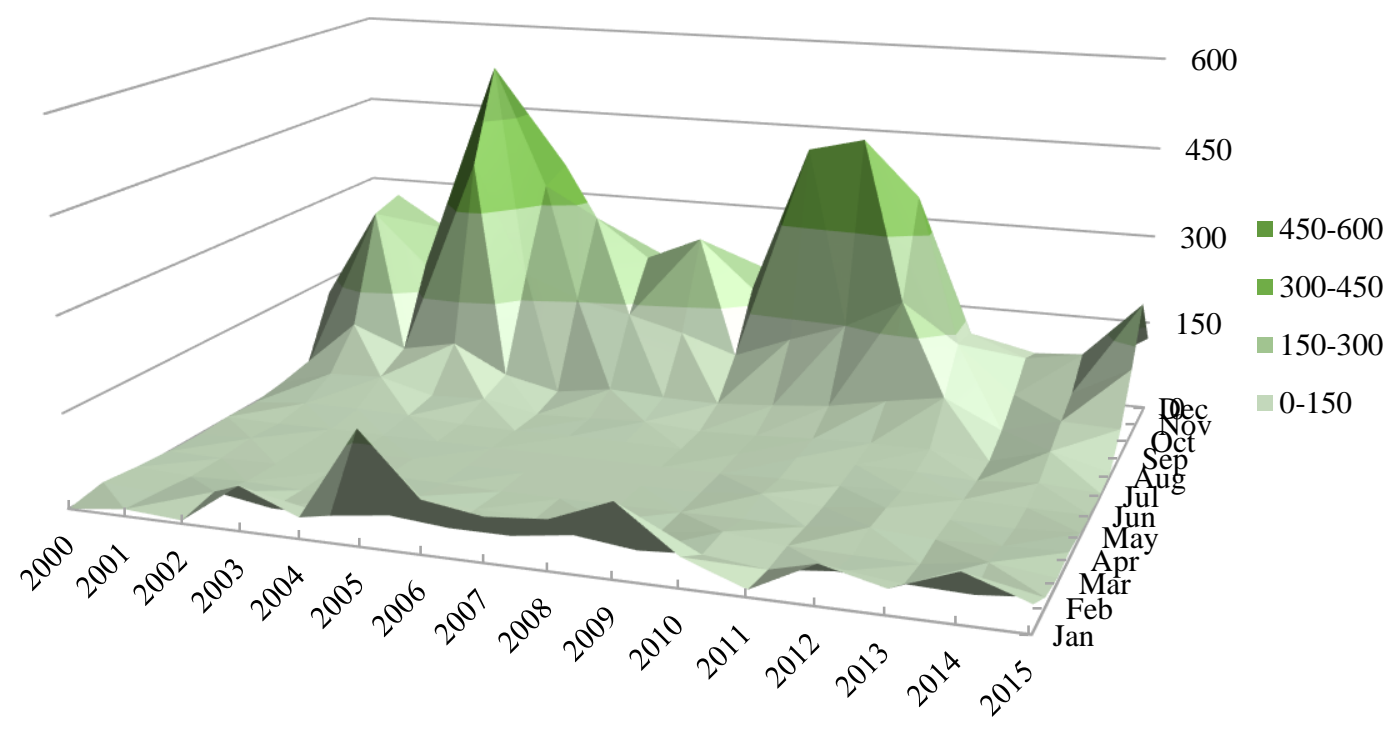

Figura 2. Focos de calor nos municípios do estado da Paraíba (eixo z) detectados mensalmente pelos satélites referência do INPE entre os anos de 2000 a 2015.

Figure 2. Heat sources in the municipalities of the state of Paraíba (z-axis) detected monthly by the reference satellites of INPE between the years of 2000 to 2015 .

The period with the highest frequency of hotspots for all the studied regions was from September to December, with approximately $80 \%$ of occurrences. Regarding the individual analysis of the municipalities, separating them in their respective mesoregions, the data of heat sources of reference satellites available in the INPE archives were used. In this way, a total of 3,712 hotspots were recorded (Table 1).

Tabela 1. Focos de calor detectados pelos satélites do Instituto Nacional de Pesquisas Espaciais (INPE) em um período de 15 anos em seis municípios da Paraíba.

Table 1. Heat sources detected by satellites of the National Institute of Space Research (INPE) over a period of 15 years in six municipalities of Paraíba.

FLORESTA, Curitiba, PR, v. 49, n. 2, p. 181-188, abr/jun 2019.

Novaes. D. B. et.al.

ISSN eletrônico 1982-4688

DOI: $10.5380 /$ rf.v49 i 2.55112 


\begin{tabular}{ccccccc}
\hline & \multicolumn{6}{c}{ Mesoregion } \\
\cline { 2 - 7 } Year & Forest & & Agreste & Borborema & \multicolumn{2}{c}{ Sertão } \\
& João Pessoa & Areia & Campina Grande & Monteiro & Cajazeiras & Patos \\
\hline 2000 & 0 & 0 & 0 & 26 & 22 & 4 \\
2001 & 1 & 1 & 5 & 21 & 56 & 4 \\
2002 & 3 & 1 & 4 & 38 & 214 & 6 \\
2003 & 3 & 0 & 10 & 117 & 441 & 42 \\
2004 & 1 & 3 & 22 & 98 & 298 & 10 \\
2005 & 2 & 5 & 6 & 84 & 175 & 9 \\
2006 & 8 & 4 & 5 & 77 & 299 & 17 \\
2007 & 0 & 0 & 5 & 57 & 78 & 12 \\
2008 & 6 & 1 & 1 & 85 & 180 & 1 \\
2009 & 6 & 5 & 0 & 64 & 124 & 15 \\
2010 & 0 & 3 & 0 & 58 & 73 & 7 \\
2011 & 2 & 0 & 0 & 121 & 56 & 4 \\
2012 & 5 & 2 & 7 & 53 & 76 & 71 \\
2013 & 4 & 3 & 2 & 56 & 35 & 20 \\
2014 & 2 & 1 & 0 & 44 & 47 & 1 \\
2015 & 8 & 9 & 9 & 51 & 79 & 21 \\
\hline Total & 51 & 38 & 76 & 1,050 & 2,253 & 244 \\
\hline
\end{tabular}

Since these values came only from the database of reference satellites, they do not accurately express the actual number of hotspots occurred, because they only detect the larger ones. However, these data serve to give an idea of the scenario in the state, in which years with higher incidences of heat sources may be linked to the meteorological conditions and, as observed by Tetto et al. (2012) for Paraná between 2005 and 2010, anthropic actions, such as land occupation and land management.

In the municipality of João Pessoa, there was an annual average of 3.18 heat sources, with the highest occurrence of eight hotspots in 2006 and 2015, which corresponds to $31.2 \%$ of the records (Figure 3), totaling 51 heat sources in 15 years (Table 1). As it is a coastal municipality, the rains that occur frequently and the constant humidity, coming from the ocean, can be factors that prevent the propitious conditions for fire occurrence and propagation.

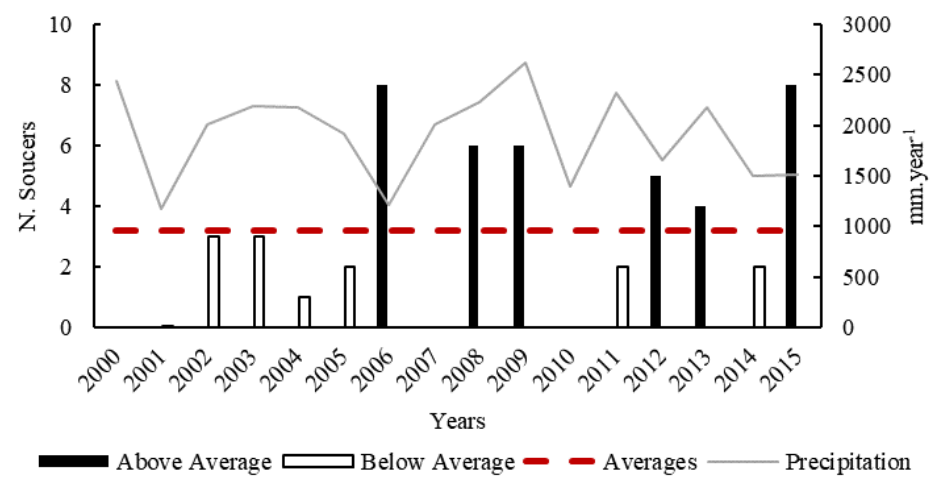

Figura 3. Focos de calor em João Pessoa-PB, mesorregião Mata Paraibana, detectados pelos satélites do INPE entre os anos de 2000 a 2015.

Figure 3. Heat sources in João Pessoa-PB, Mata Paraibana mesoregion, detected by INPE satellites between 2000 and 2015 .

In the municipalities located in the Agreste mesoregion, there were 114 heat sources (Table 1), with an annual average of 2.37 and 4.75 hotspots recorded in Areia and Campina Grande, respectively (Figure 4). It was possible to observe that, despite the differences in the years 2004, 2005, 2006 and 2015, the hotspots were above average in the municipalities. The results indicate that the climatic characteristics of each mesoregion influence the heat sources. 
(a)

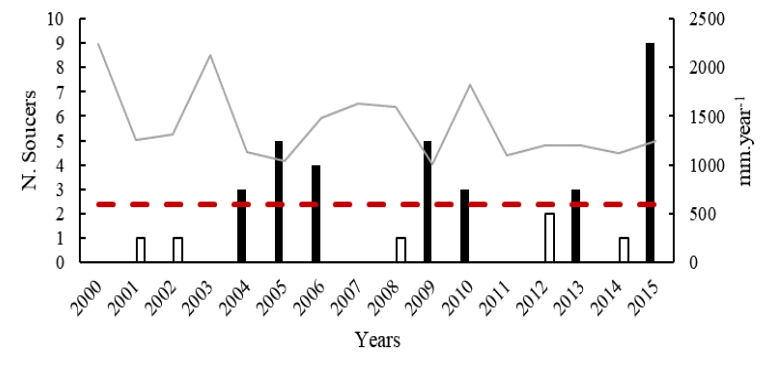

(b)

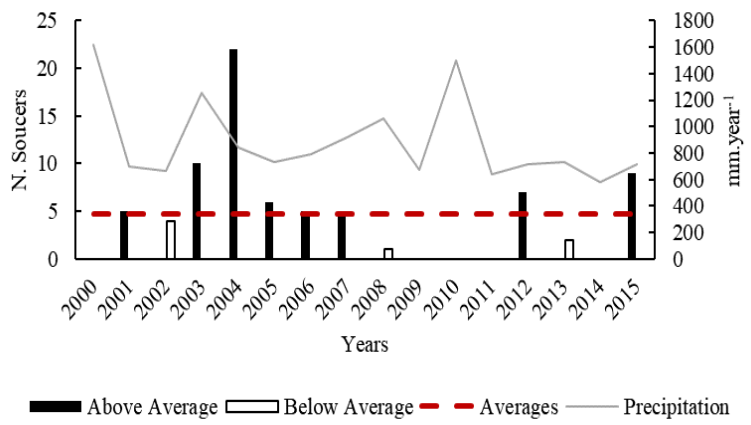

Figura 4. Focos de calor nos municípios de Areia (a) e Campina Grande (b), mesorregião Agreste, detectados pelos satélites do INPE entre os anos de 2000 a 2015.

Figure 4. Heat fluxes in the municipalities of Areia (a) and Campina Grande (b), Agreste mesoregion, detected by INPE satellites between 2000 and 2015 .

Among the municipalities studied, Monteiro presented the second highest number of heat sources in 15 years, with $28.28 \%$ of the records with an average of 65.62 hotspots per year (Figure 5). It was also observed that, in 2003 and 2004, Monteiro followed the trend of Paraíba in the years of higher incidence of heat sources (Figure 2); in contrast, 2011 was the year with the highest recording of hotspots (121), diverging from the results for the state.

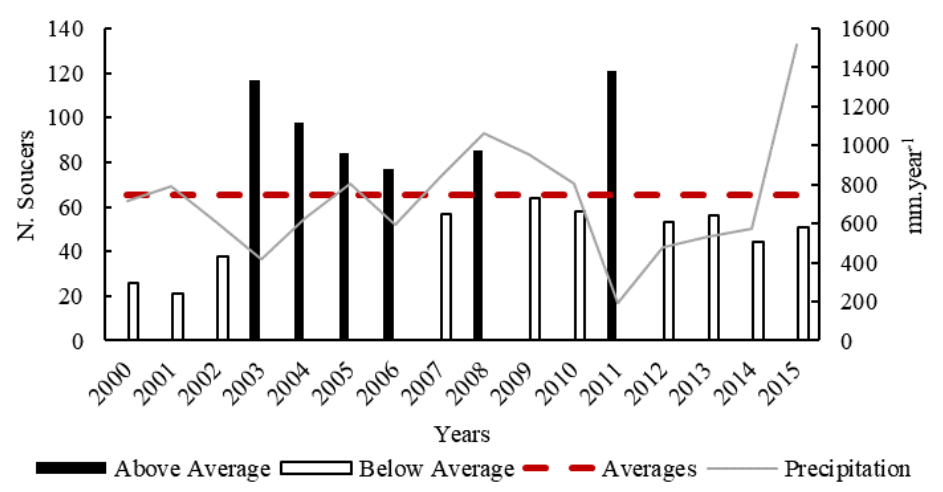

Figura 5. Focos de calor em Monteiro, mesorregião da Borborema, detectados pelos satélites do INPE entre os anos de 2000 a 2015.

Figure 5. Heat fluxes in Monteiro, Borborema mesoregion, detected by INPE satellites between 2000 and 2015.

In the mesorregião of Sertão, the municipalities of Cajazeiras and Patos (Figure 6) were analyzed, being registered, in 15 years in Cajazeiras, (6a) 2,253 heat sources, representing $60.70 \%$ of the total (Table 1). With an average of 140.81 hotspots per year, Cajazeiras had a consecutive period, 2002 to 2006, of above average heat sources, reaching the highest value in 2003 (441 hotspots). In the period from 2009 to 2015, below average heat sources were identified, indicating that there was probably some anthropogenic or natural event that caused this behavior. 
(a)

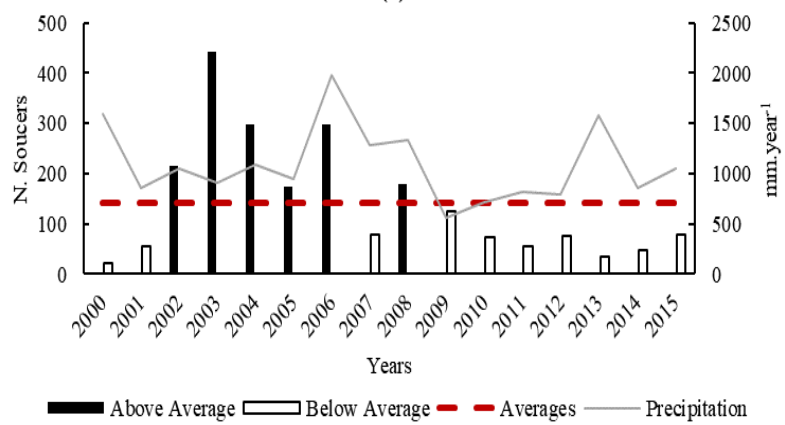

(b)

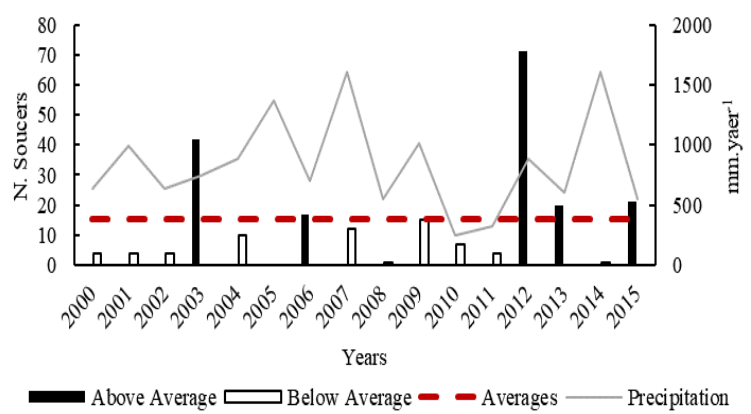

Figura 6. Focos de calor nos municípios de Cajazeiras (a) e Patos (b), mesorregião Sertão paraibano, detectados pelos satélites do INPE entre os anos de 2000 a 2015.

Figure 6. Heat sources in the municipalities of Cajazeiras (a) and Patos (b), Sertão paraibano mesoregion, detected by INPE satellites from 2000 to 2015 .

Finally, in the municipality of Patos (6b), 244 heat sources were detected (Table 1), with an average of 16.20 hotspots per year. This municipality, despite the high number of hotspots, had only five years of above average records (Figure 6), with 2012 in the spotlight. This region was once a major producer of cotton and soybeans. However, in recent years, the subsistence agriculture has been emphasized, yet it still uses a lot of fire to clean the land, which, combined with high temperatures throughout the year and low rainfall, increases the amount of heat sources, as well as their intensities and range.

\section{DISCUSSION}

Between September and December (Figure 2) there are elevations of average temperatures in the state, in addition to low or nonexistent rainfall indexes (SANTOS et al., 2015). Meanwhile, Soares et al. (2006) assessed the evolution of forest fires in protected areas in Brazil, they found that the fire season was between June and November, with peaks in August and September, being eucalyptus the most affected by fire, followed by natural formations, diverging from that observed for the state of Paraíba in the present study.

However, Torres et al. (2017) mapping the risk of forest fires through geoprocessing techniques found that the occurrence of hotspots in forest areas was 4 times higher than the forest cultivation, not only surpassing the grasslands, possibly due to practices to renewal the same ones, but reinforcing the importance of knowing the particularities of each region, which allows to concentrate the efforts of prevention and combat in specific periods, avoiding wear of human and financial resources, thus, turning the strategies more efficient.

In João Pessoa, the (Figure 3) recorded heat sources may be related to agricultural activities, in which, in the management of sugarcane, the primitive practice of burning the straw is still used to facilitate harvesting (PEREIRA; SILVA, 2016). Analyzing the temporal distribution of hotspots, the relation with the harvest months of sugarcane was observed, which in the Northeast occurs between November and April, followed by the reduction in the off-season, mainly affecting the ecosystems of the Atlantic forest.

It is also observed in the municipality of João Pessoa, for the years 2008 and 2009 a high occurrence of heat sources, despite the rains. This behavior can be explained by the fact that, even in those two years the rainfall was abundant, with 109 days of precipitation above $10 \mathrm{~mm}$ and distributed throughout the year, with peaks between March and August (INMET, 2018), heat above the average were observed. Such behavior can also be explained by the management practices that use fire as a tool. According to data from the Union of Sugarcane Industry (UNICA, 2018), in the state of Paraíba the sugarcane production jumped from 4.90 thousand tons in 2007 to 6.24 thousand tons in 2009, an increase of $27.3 \%$, which can be explained by the increased availability of water to the cultivation, favoring the production of biomass by plants.

The discrepancy between the municipalities is motivated by the relief and climate characteristics inherent to each one, and the municipality of Areia (4a), for example, is located in a swamp altitude, which leads to milder temperatures, higher humidity and higher rainfall rates. In the municipality of Campina Grande (4b), rainfall rates are lower and rains more irregular than in Areia, which leaves it more vulnerable to the incidence of heat sources.

According to Santos et al. (2015), this mesoregion is intensely individualized in relation to environmental heterogeneity as much as the temporal space and, mainly, to the meteorological parameters. According to the aforementioned authors, the environmental conditions, associated with the transition between the coast and the 
backlands of the state, favor the presence of a highly diversified vegetation, such as Campina Grande, which, because it is located near the Borborema mesoregion, has a hyperxerophilic caatinga.

The municipality of Monteiro (Figure 5) is located in the Borborema mesoregion, a region characterized by low rainfall and a long dry season. According to Pereira e Silva (2016), these meteorological conditions are ideal in starting fires, caused mainly by small-scale livestock and subsistence agriculture, practices very common in this mesoregion, which use fire in its management annually and almost always without control.

The Sertão Paraibano was the mesoregion with the highest number of heat sources, totaling 2,487 between 2000 and 2015 , corresponding to $67.28 \%$ of the total. The data indicate that this mesoregion is vulnerable to fire and that it urgently needs strategies to mitigate this reality, being it awareness programs for the rural man, preventive practices or personnel training for efficient combat in critical periods. Pereira e Silva (2016) analyzed heat sources in all municipalities of Paraíba in the year of 2014 and concluded that in Sertão, there were $33.7 \%$ of hotspots between the four mesoregions, probably connected to the characteristics of the semiarid region.

\section{CONCLUSIONS}

- The data detected by satellites allow observing the incidence of heat sources in the six municipalities selected for the study.

- The occurrence of heat sources is not a regular phenomenona in Paraíba, varying between years, mesoregions and municipalities, but for the whole state, a predominance of hotspots in the months of September and December was observed.

- Agricultural activities, such as sugarcane harvesting, favor the elevation of heat sources in the state, especially in the municipality of João Pessoa.

- The Sertão Paraibano mesoregion is the one with the highest number of heat sources in the state of Paraíba.

- The results allow the creation of strategies to combat hotspots in the months of greater frequency, avoiding human, financial and environmental losses.

- It is necessary to implement awareness programs through local authorities providing information on the importance of adequate fire management to the citizen of rural and urban areas.

\section{REFERENCES}

FRANCISCO; P. R. M.; MEDEIROS; R. M. DE; MATOS, R. M. DE; MARIA MARLE BANDEIRA, M. M.; SANTOS; D. Análise e Mapeamento dos Índices de Umidade, Hídrico e Aridez através do BHC para o Estado da Paraíba. Revista Brasileira de Geografia Física, v.8 n.4, p.1093-1108, 2015.

GRANEMANN, D. C.; CARNEIRO, G. L. Monitoramento de focos de incêndios e áreas queimadas com a utilização de imagens de sensoriamento remoto. Revista de Engenharia e Tecnologia, Ponta Grossa, v. 1, n. 1, p. 55-62, 2009.

INSTITUTO BRASILEIRO DE GEOGRAFIA E ESTATÍSTICA (IBGE). Estados. Disponível em:

<https://www.ibge.gov.br/estatisticas-novoportal/por-cidade-estado-estatisticas.html?t=destaques\&c=25>.

Acesso em: 28mai 2018.

INSTITUTO NACIONAL DE METEOROLOGIA (INMET). Estações e Dados. Disponível em:

<http://www.inmet.gov.br/portal/index.php?r=bdmep/bdmep>. Acesso em: 10 de ago de 2018.

INSTITUTO NACIONAL DE PESQUISAS ESPACIAIS (INPE).Programa Queimadas. Disponível em: <http://www.inpe.br/queimadas/>. Acesso em: 03 jan. 2017.

PEREIRA, A. A.; BARROS, D. A.; PEREIRA, J. A. A.; JUNIOR, F. W. A.; MORELLI, F.; SCOLFORO, J. R. S. Frequência espacial- temporal dos focos ativos em Minas Gerais durante o período de 1999 a 2009. Revista Cerne, Lavras, v. 20, n. 3, p. 459-469, 2014.

PEREIRA, J. A. V.; SILVA, J. B. Detecção de focos de calor no Estado da Paraíba: Um estudo sobre as queimadas. Revista Geografia Acadêmica, Boa Vista, v. 10, n. 1, p. 5-16, 2016.

RAMOS, R. M.; FONSECA, R. L.; MORELLO, T. F. Unidades de conservação e proteção contra incêndios florestais: Relação entre foco de calor e ações articuladas pelas brigadas contratadas. Biodiversidade Brasileira, Brasília, v. 6, n. 2, p. 135-148, 2016.

FLORESTA, Curitiba, PR, v. 49, n. 2, p. 181-188, abr/jun 2019. 
RODRIGUES, N. S.; SIlvA, L. C. M.; OliveirA, A. F.; PINIllos, A. C. M. SOUZA, C. A. Análise da distribuição espaço-temporal e quantificação de focos de calor, na área fisiogeográfica do Pantanal MatoGrossense. Enciclopédia Biosfera, Curitiba, v. 10, n. 19, p. 2951-2964, 2014.

SANTANA, J. A. S.; ARAUJO, I. M. M.; SENA, C. M.; PIMETA, A. S.; FONSECA, F. C. E. Determinação dos períodos críticos de ocorrência de incêndios florestais na Estação Ecológica do Seridó, Serra Negra do Norte-RN. Revista Caatinga, Mossoró, v. 24, n. 1, p. 43-47, 2011.

SANTANA, J. A. S.; SOUTO, J. S. Diversidade e estrutura fitossociologica da Caatinga na EstaçãoEcológica do Serido-RN. Revista de Biologia eCiências da Terra, Campina Grande, v. 6, n. 2, p. 232-242, 2006.

SANTOS, W. S.; SOUTO, P. C.; SOUTO, J. S.; MENDONÇA, I. F. C.; SOUTO, L. S.; MARACAJÁ, P. B. Estimativa dos riscos de ocorrência de incêndios florestais no Parque Estadual Pico do Jabre, na Paraíba. Agropecuária Científica do Semiárido, Patos, v. 11, n. 1, p. 80-84, 2015.

SOARES, A. S. D.; PAZ, A. R.; PICCILLI, D. G. A. Avaliação das estimativas de chuva do satélite TRMM no Estado da Paraíba. Revista Brasileira de Recursos Hídricos, Porto Alegre, v. 21, n. 2, p. 288-299, 2016.

SOARES, R. V.; BATISTA, A. C.; SANTOS, J. F. Evolution of forest fire statistics in Brazilian protected lands in the last 20 years. Forest Ecology and Management, v. 234, p. S239-S239, 2006.

SORIANO, B. M. A.; DANIEL, O.; SANTOS, S. A. Eficiência de índices de risco de incêndios para o pantanal Sul-Mato-Grossense. Revista Ciência Florestal, Santa Maria, v. 25, n. 4, p. 809-816, 2015.

SUPERINTENDÊNCIA DE ADMINISTRAÇÃO DO MEIO AMBIENTE (SUDEMA). Atualização do diagnóstico florestal do Estado da Paraíba. João Pessoa: SUDEMA, 2004. 268p.

TETTO, A. F.; BATISTA, A. C.; SOARES, R. V. Ocorrência de incêndios florestais no Estado do Paraná, no período de 2005 a 2010. Revista Floresta, Curitiba, v. 42, n. 2, p. 391-398, 2012.

TORRES, F. T. P.; ROQUE, M. P. B.; LIMA, G. S.; MARTINS, S. V.; FARIA, A. L. P. Mapeamento do Risco de Incêndios Florestais Utilizando Técnicas de Geoprocessamento. Revista Floresta e Ambiente, v. $24,2017$.

TORRES, F. T. P.; LIMA, G. S.; COSTA, A. G.; FÉLIX, G. A.; JÚNIOR, R. M. S. Perfil dos incêndios florestais em unidades de conservação brasileiras no período de 2008 a 2012. Revista Floresta, Curitiba, v.46, n. 4, p. 531$542,2016$.

VAREJÃO-SILVA M. A.; BRAGA, C. C.; AGUIAR M. J. N.; NIETZCHE M. H.; SILVA, B. B. Atlas Climatológico do Estado da Paraíba. UFPB, Campina Grande, 1984.

UNIÃO DA INDÚSTRIA DE CANA-DE-AÇÚCAR (ÚNICA). Histórico de Produção e Moagem. Disponível em:

$<$ http://www.unicadata.com.br/historico-de-producao-e-

moagem.php idMn=32\&tipoHistorico $=4 \&$ acao $=$ visualizar\&idTabela $=1984 \&$ safra $=2009 \% 2 F 2010 \&$ estado $=P B>$

. Acesso em: 28 mai 2018. 